\title{
Financial Leasing Decision-making and Pricing Method for Highway Project
}

\author{
Hong Zhang, Dingyou Lei, Qiongfang Zeng and Yinggui Zhang* \\ School of Traffic and Transportation Engineering, Central South University, \\ Changsha, China \\ Email : ygzhang@csu.edu.cn(Correspondening author)
}

\begin{abstract}
Reasonable financial leasing decision-making and pricing mechanism is the key for highway project that requires large amount of construction funds, and after-sales leaseback financial leasing mode can be well applied in financial leasing business of highway project. Based on financial real option theory, we put forward both financial leasing valuation model and binary tree option pricing model in the paper. Firstly, we analyzed real option value of financial leasing. Then, financial leasing decision-making and pricing model for highway project was built, and financial leasing decision-making and pricing method for highway project was further proposed. These models put forward in the paper can provide theoretical support for financial leasing decision-making and pricing for highway project.
\end{abstract}

Keywords: highway project, after-sales leaseback, financial leasing, decision-making model, pricing model

\section{Introduction}

Highway construction is a typical capital-intensive industry and requires a lot of money, manpower and material resources. Highway project investment and financing have been the most intractable problem for highway construction all around the world, and many countries have formulated legislations or imposed administrative measures to build an effective management system composed of central finance, project finance and special fund systems. Bayraktar and Hastak developed a decision support system for selecting the optimal contracting strategy in highway work zone projects [1], Li and Chen studied the sustainable development of highway construction projects with BP neural network algorithm [2]. Also, Xu and Grant-Muller, et al., illustrated and analzyed economic regulatory policies for highway infrastructure in China [3]. Omid and Deb, et al., constructed an integrated modeling framework for leasing urban roads [4]. Besides, Mishra and Khasnabis, et $a l$., put forward a simulation approach for estimating value at risk in transportation infrastructure investment decisions [5], and Khmel and Zhao given an arrangement of financing for highway infrastructure projects under the conditions of PublicPrivate Partnership [6]. Furthermore, Tiong and Yeo have taken project financing as a competitive strategy in winning overseas jobs [7]. Su pointed out that important characteristics of financial leasing business such as "use rights can be separated" can not only help solving the funding problems on highway project construction, but also help improving highway enterprise's financial situation and reducing assetliability ratio [8]. After-sales leaseback method can not only optimize highway enterprise's capital structure without changing highway management and operation but also raise a large amount of funds in time [9]. Ezzell and Vora proposed that, among all lease types, the value increase on lessee's right in after-sales leaseback mode is significant, whereas the right value increase in direct lease mode is not so 
significant. And they also point out that direct lease gains less income than aftersales leaseback when lessee is leasing assets that have a guaranteed residual values and sensitive frequencies of utilization [10]. On the above basis, we apply aftersales leaseback mode to highway project investment and financing process and then design financial leasing decision-making and pricing method for highway project in this paper.

\section{Analysis of Highway Financial Leasing}

The deal structure in after-sales leaseback mode is shown in figure 1. Its feature is that supplier of equipment and lessee are the same person, therefore, only lessor and lessee are involved. The lessee can realize stock assets through after-sales leaseback, which means that the materialized assets will be turned into currency assets with strongest liquidity. Thus, the shortage of liquidity and equity investment are partly resolved. Besides, we can also revitalize part of highway stock assets and bring considerable cash flow to highway enterprise through after-sales leaseback. For instance, if cash flow is used for loan repayment, then asset-liability ratio will be reduced and financing space will be expanded. If cash flow is used to invest some new projects, then more market opportunities can be grasped [11].

Sale or lease original assets for financing

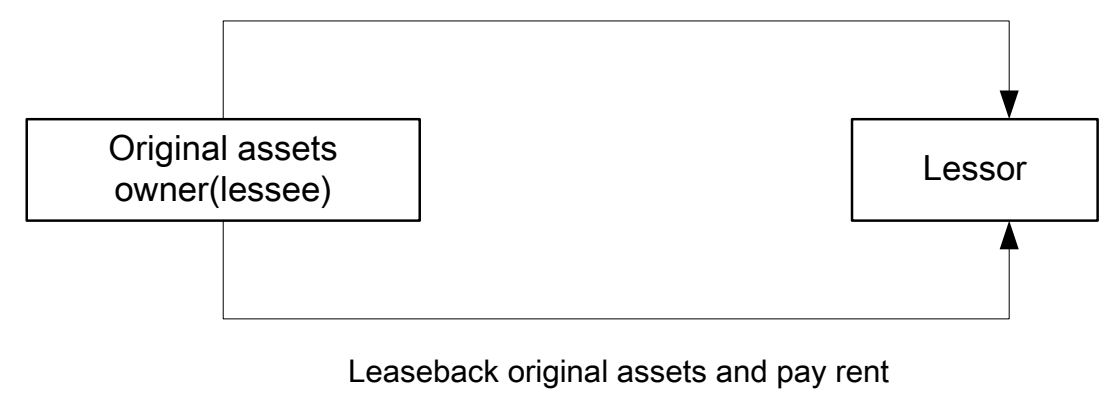

Figure 1. The Deal Structure in After-sales Leaseback Mode

For highway project, lessor refers to financial leasing company. Financial leasing company is a leasing company wholly owned or controlled by financial institutions and its main purpose is to find a new financing way that can satisfy user demand. Such type of leasing company is characterized by strong capital strength, low cost of financing, network-based of financial institutions and a large group of customers. Lessees refer to highway enterprises; namely, large state-owned investment company working on highway construction, investment, management and operation [12].

We can describe highway after-sales leaseback financing in the following process. Authorized by government and approved by relevant departments, lessee transfers highway's fixed assets from lessee to lessor, and lease the fixed asset from lessor back to use. During the lease term, lessee shall not transfer, mortgage, guarantee or sublease fixed asset, while lessor shall not interfere in the normal use of fixed assets by lessee. Lessee shall pay off rent and other accounts payable after lease term expired and repurchase lessor's fixed assets at prices agreed in contract.

In highway financial leasing contract, lease item, rent, project supervision, information disclosure, rights and obligations of each side, processing problems and guarantee of the contract should be stipulated in explicit terms. In highway financial leasing contract, highway lease item refers to both fixed assets and underlying assets in assets transfer contract. Lessees refer to highway enterprises that should provide and confirm specific information of lease item including name, 
specification, quantity and technical standards; besides, they are also responsible for its authenticity, integrity and legality. Issues related to lease item should also be stipulated in the contract in detail, such as ownership of lease item, purchase, delivery, acceptance, use, storage, maintenance, related taxes, related fees, assumption of damage or loss risks, insurance and other items to deal with after the contract terminated [13]. Highway financial leasing rent is also composed of principal and interest in different leasing periods. Leasing principal is the total payment in asset transfer contract, and leasing interest is calculated according to actual day. It can be calculated as follows:

Leasing Interest $=$ Leasing Principal $*$ Lease Rates $/ 360$ (The actual day).

Rental rates are determined by adding a certain percentage to RMB benchmark lending rate in $\mathrm{X}$ term ( $\mathrm{X}$ is defined by rent length) which is published by People's Bank of China. After-sales leaseback is the most effective mode to transfer materialized assets with poor liquidity to cash assets with the strongest liquidity without changing enterprise's assets use. This leasing mode can act as a "bridge" of assets realization. In operation process, highway enterprises often get into payment difficulties or financial crisis in a worsen situation which are caused by insufficient liquidity. Therefore, keeping assets liquidity is essential for its normal operation and investment activities. In view of liquidity and profitability, income is derived from highway asset management-generally. Materialized assets themselves cause low liquidity, so enterprises need to seek more approach to transfer materialized assets into liquid cash assets and maintain moderate ratio of the two assets in the meantime. After-sales leaseback just sets up a conversion channel between the two assets forms.

\section{Decision-making Model for Financial Leasing of Highway Project}

We build decision-making model for financial leasing in highway projects based on the following premises:

(1) Revenue per unit time $P_{t}$ for highway project is subjected to stochastic dispersive Wiener process, namely:

$$
\frac{d P_{t}}{P_{t}}=\rho d t+\delta d z_{t}
$$

In the above equation, $\rho$ denotes instantaneous expected revenue of highway project;

$\delta$ denotes standard deviation of instantaneous expected revenue; and $d z_{t}$ denotes differential (mean is 0 and variance is $d t$ ) of a standard Wiener process.

(2) Expected revenue for highway project is risk-free interest rate, namely $r_{t}=r_{0} t$.

(3) Financial leasing market of highway project has no friction, which means that impact of taxes and transaction costs on financial leasing cost is not considered.

Combining stochastic process with ITO's theorem, we can deduce function of revenue

$$
P_{t}=P_{0} e^{\left(\rho-\frac{\delta^{2}}{2}\right) t+\delta z_{t}}
$$

In the above equation, $P_{0}$ denotes instantaneous actual revenue for highway project when financial leasing contract is signed.

Lease term for highway projects is denoted by $T$, and leasing rent in contract is denoted by $R_{T}$. Then current value of cash flow is denoted by $N R_{t}$ which is calculated by Eq. (3).

$$
N R_{t}=\int_{0}^{T} e^{-r_{0} t} R_{T} d t
$$

The current value of revenue is denoted by $N P_{t}$ which is calculated by Eq. (4). 


$$
N P_{t}=\int_{0}^{T} e^{-r_{0} t} P_{t} d t
$$

By substituting Eq. (2) into Eq. (3), we know that the current value of revenue $N P_{t}$ can be calculated by Eq. (5).

$$
N P_{t}={ }_{0}^{T} e^{r_{0} t} P_{0} e^{\left(\frac{2}{2}\right) t+z_{t}} d t=P_{0}{ }_{0}^{T} e^{\left(r_{0} \frac{2}{2}\right) t+z_{t}} d t
$$

In equilibrium and effective financial leasing market for highway project, the current value of cash flow $N R_{t}$ equals the current value of revenue $N P_{t}$.

$$
\begin{gathered}
N P_{t}=N R_{t} \\
P_{0} \int_{0}^{T} e^{\left(\rho-r_{0}-\frac{\delta^{2}}{2}\right) t+\delta z_{t}} d t=\int_{0}^{T} e^{-r_{0} t} R_{T} d t
\end{gathered}
$$

Therefore, annual rent in financial leasing contract is denoted by $R_{T}$ which is calculated by Eq. (8).

$$
R_{T}=\frac{P_{0} \int_{0}^{T} e^{\left(\rho-r_{0}-\frac{\delta^{2}}{2}\right) t+\delta z_{t}} d t}{\int_{0}^{T} e^{-r_{0} t} d t}
$$

We may further assume that standard deviation for instantaneous revenue per unit time is zero $(\delta=0)$, and annual rent $R_{T}$ for traditional highway project in contract is calculated

$$
R_{T}=\frac{P_{0} \int_{0}^{T} e^{\left(\rho-r_{0}\right) t} d t}{\int_{0}^{T} e^{-r_{0} t} d t}=P_{0} \frac{-\frac{1}{r_{0}-\rho}\left(e^{\left(\rho-r_{0}\right) T}-1\right)}{-\frac{1}{r_{0}}\left(e^{-r_{0} T}-1\right)}=P_{0} \frac{r_{0}}{r_{0}-\rho} \frac{e^{\left(\rho-r_{0}\right) T}-1}{e^{-r_{0} T}-1}
$$

In after-sales leaseback mode, the rent in financial leasing contract is composed of fixed rent and revenue for highway project, which means that operation enterprises repay part of the revenue to lessor as rent. As for lessors of highway project such as Banks and other financial institutions or enterprises, it is pointed out that rent contains a call option of lessor, which is different from traditional way of financial leasing payment, and this part of rent is called contingent rent. The contingent rent is associated to use revenue for highway enterprise, and such a leasing mode with contingent rent can also been regarded as a leasing mode.

Let $R_{F}$ denotes fixed rent paid by lessee to lessor. Let $P_{a}$ denotes lower limitation for revenue in leasing mode with contingent rent. Let $\eta$ denotes revenue-sharing ratio for highway project at the moment of $t$, and then financial leasing rent for highway project can be calculated by Eq. (10).

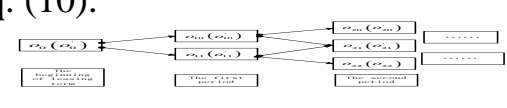

Then, financial leasing rent flow for highway project can be calculated by Eq. (11)

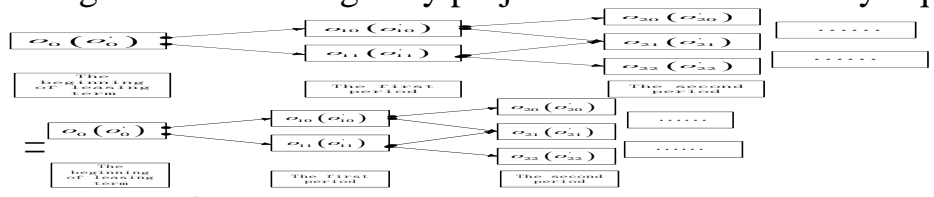

It is easy to deduce Eq. (12) from Eq. (6).

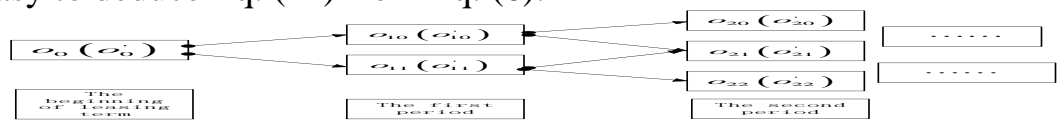

Therefore, we come to get Eq. (13). 


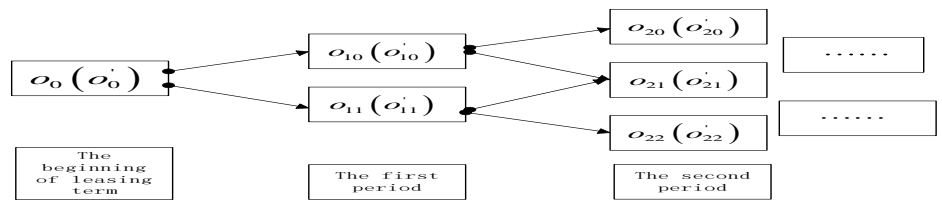

(13)

Namely, fixed rent

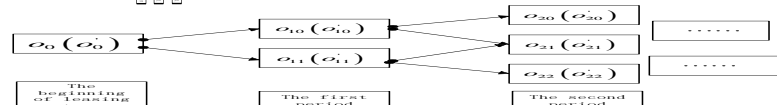

Let

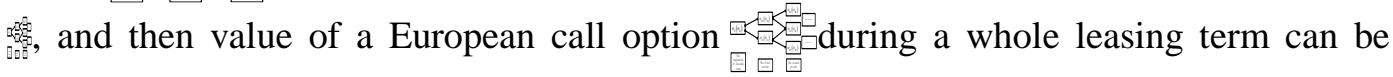
calculated by Eq. (15).

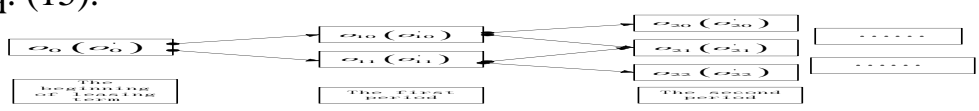

(15)

If investors receive dividends from project revenue, then fixed rent 蝫 can be rewritten as Eq. (16) .

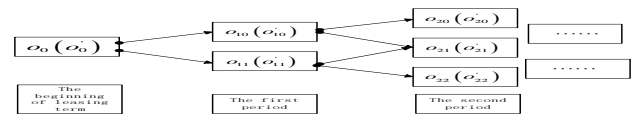

Highway enterprises generally do not give up option within the financial leasing terms. European call option means that highway enterprises may take back ownership of leased assets when financial leasing term expires. An American put option means that highway enterprise may give up options or cancel project within time limit for various reasons including a poor operating conditions or bleak outlook. In after-sales leaseback mode, lessee rents highway back from lessor's hand, so that the lessee can finance or attract a certain amount of money to build or operate highway continually.

\section{Pricing model for Highway Financial Leasing}

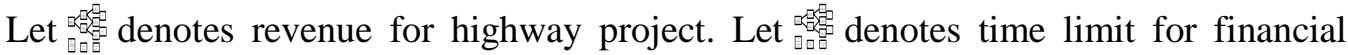
leasing. Combined with computer simulation precision requirements, financial leasing term for highway project can be divided into 䠤 stages or periods, namely

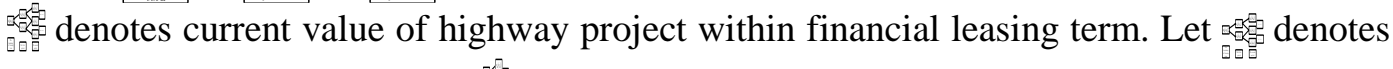

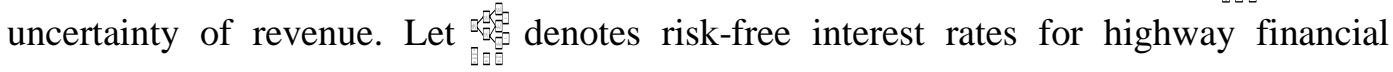
leasing market.

According to binary tree with real option valuation model, revenue for highway project in each successive time periods are subjected to the following multiplier binary tree process. It means that revenue for highway project goes through 呾 time (each successive time) with risen and fallen states, which form two new nodes. Let

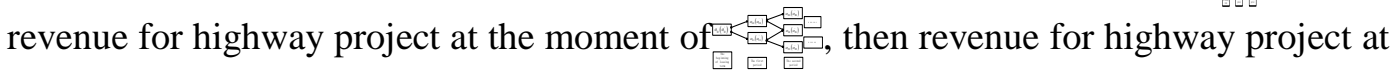

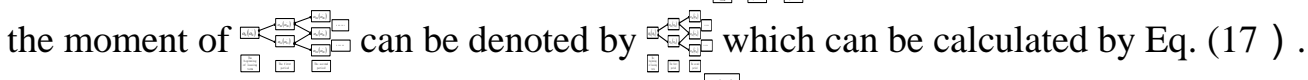

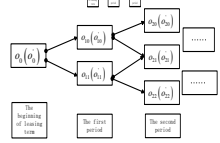

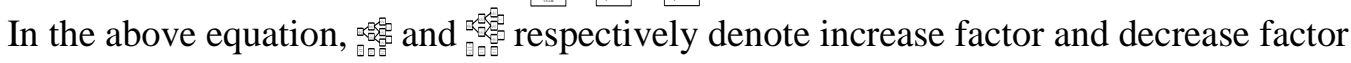


of revenue for highway project, namely drift rates, and then

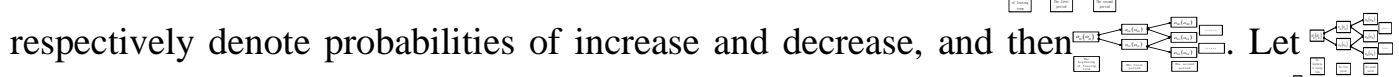
denote revenue for highway project after revenue increase in time period of denote revenue for highway project after revenue decrease in time period of

It is reasonable to use basic financial option pricing model, because real option itself is application of financial option theory on real assets [14]. In option theory, it is generally assumed that distribution of underlying assets value is the logarithmic normal distribution. In this paper, we continue to use such assumption in this paper $[15,16]$. Thus, increase factor, decrease factor, increase probabilities and decrease probabilities can be respectively calculated by Eq. (18-21).

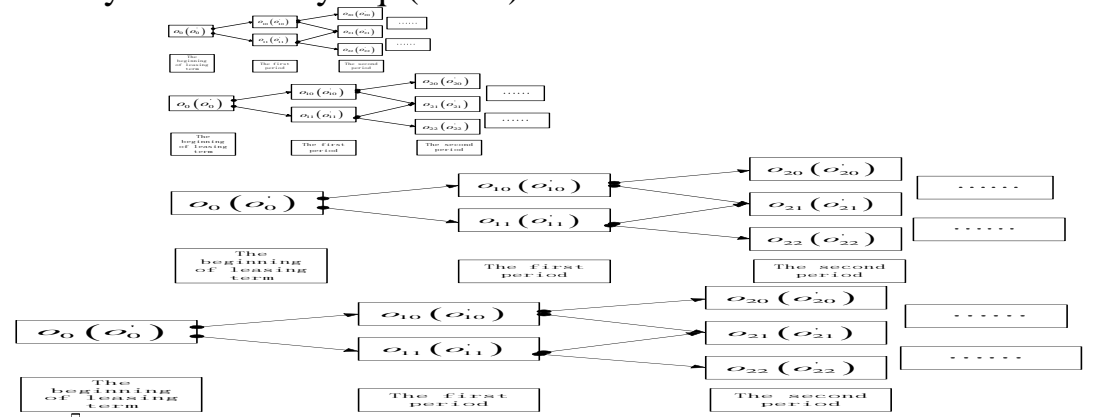

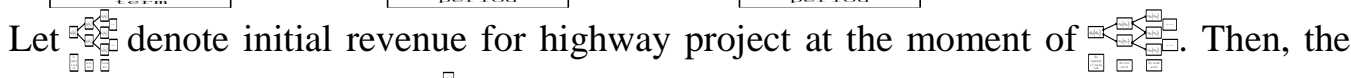
revenue of highway project

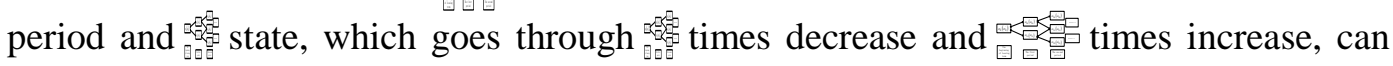
be calculated by Eq. (22).

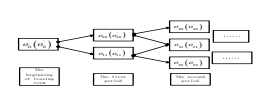

Combined with option theory, we come to know that revenue for highway in each period corresponds to remaining value for fixed rent during this period in the financial leasing option pricing model. Let beginning of leasing term. Let Combined with Eq. (16), we can calculate

$$
\text { and }
$$

In our country, if highway enterprises just can't pay rent to lessor in regular way for various reasons such as poor operation or bleak outlook, it is generally national government agencies such as the JPCD pay the money and guaranty bond. And when financial leasing term expires, highway enterprise generally will take back ownership. We assume that highway companies will not cancel highway project within financial leasing term, and they will take back ownership after financial leasing term expired.

Therefore, we need to calculate remaining value 㗊 in operation. On the above basis, we come to know that revenue for highway project in

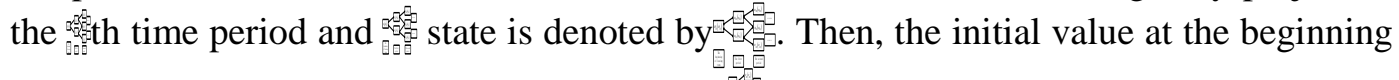
of financial leasing term can be denoted by

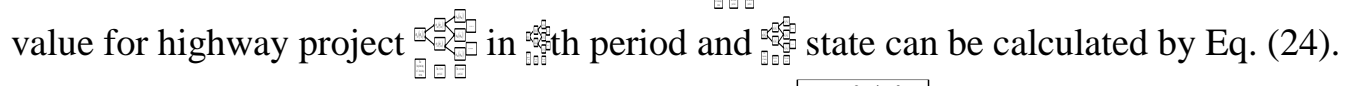

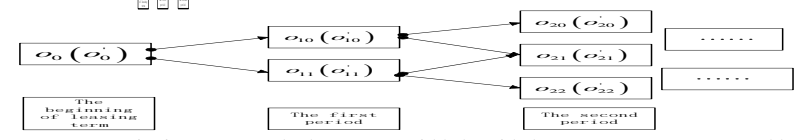

Based on binary tree pricing model, we will build a European call option pricing model for financial leasing of highway project. The model structure is shown in Figure 2. 


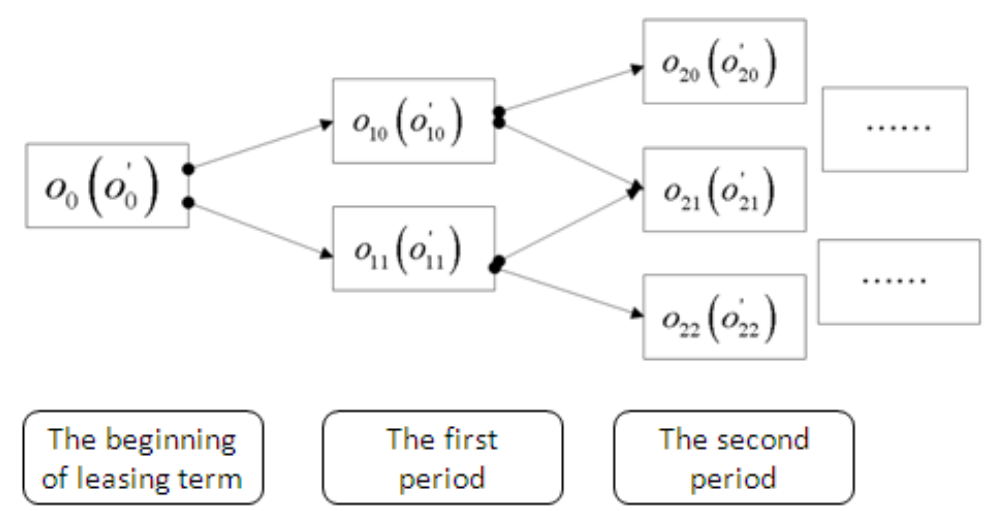

\section{Figure 2. The Pricing Model Structure for a European Call Option}

In Figure 2, $O_{i, k}^{\prime}$ denotes actual interior value, namely the NPV for highway project in the $i$ th period and $k$ state. Let $O_{i, k}$ denotes European call option value when project is in the $i$ th period and $k$ state. Let $O_{0}$ and $O_{0}^{\prime}$ respectively denote European call option value and the NPV of highway project at the beginning of leasing term. Actual interior value $O_{i, k}^{\prime}$ can be calculated by Eq. (25).

$$
O_{i, k}^{\prime}= \begin{cases}S_{i, k}^{\prime}-K_{i} & S_{i, k}^{\prime} \geq K_{i} \\ 0 & S_{i, k}^{\prime}<K_{i}\end{cases}
$$

European call option pricing method base on binary tree generally calculate real option value by retracing along the tree. Similarly, retracing method is used to calculate European call option value at the beginning of leasing term.

$$
O_{i, k}=\left(1+r_{0}\right)^{-1} \cdot\left(q \max \left\{O_{i+1, k}, O_{i+1, k}^{\prime}\right\}+p \max \left\{O_{i+1, k+1}, O_{i+1, k+1}^{\prime}\right\}\right)
$$

Combining the NPV for highway project $O_{i, k}^{\prime}$ in the $N$ th period and different states with Eq. (17) (26), we can retrace European call option value in different periods and states, and obtain $O_{0}^{\prime}$ that denotes European call option value at the beginning of financial leasing term.

Based on above analysis, leased assets value for highway project, namely rent flow, is a sum of current revenue value and European call option value in equilibrium and effective rental market. However, if we don't consider European call option value for highway project assets, financial leasing rent flow at the moment of $t$ can be denoted by $R_{t}{ }^{\prime}$ which is calculated by Eq. (27) $\sim(29)$.

$$
\begin{aligned}
& R_{t}{ }^{\prime}=R_{F}+\max \left\{0, \eta\left(P_{t}-P_{a}\right)\right\} \\
& R_{F}=R_{T}-\frac{\eta r_{0}}{1-e^{-r_{0} t}} \int_{0}^{T} e^{-r_{0} t} c^{s}\left(P, t, P_{a}\right) d t \\
& R_{T}=P_{0} \frac{r_{0}}{r_{0}-\rho} \frac{e^{\left(\rho-r_{0}\right) T}-1}{e^{-r_{0} T}-1}
\end{aligned}
$$

When investors are receiving dividends, they should consider European call option value for financial leasing assets in highway project ${ }^{[17]}$. Rent is paid annually within leasing term, and then rent flow can be calculated by Eq. (30).

$$
R_{t}^{\prime \prime}=\frac{r_{0}}{1-e^{-r_{0} T}} O_{0}+R_{F}+\eta \max \left\{0,\left(P_{t}-P_{a}\right)\right\}
$$


Because of many factors such as random rent existed within leasing term, traditional leasing decision-making and pricing methods are difficult to meet the demand. Combining with European call option value, we can solve such problems by using binary tree pricing model.

\section{Conclusions}

In the paper, we applied after-sales leaseback financial leasing model to highway project investment and financing process and designs specific highway financial leasing mode. Using real option theory and financial option theory, we construct a decision-making model for highway financial leasing. Combining with binary tree pricing model, we quantitatively analyze European call option value of highway project and propose financial leasing decision-making and pricing methods for highway project. Besides, we discussed financial leasing decision-making and pricing mechanism for highway project based on after-sales leaseback mode, which can provide theoretical support for financial leasing decision-making and pricing for highway project.

\section{ACKNOWLEDGEMENTS}

The work described in this paper was support by grants from National Natural Science Foundation of China (NSFC) (71371193).

\section{References}

[1] M. E. Bayraktar and M. Hastak, Automation in Construction, vol. 6, no. 18, (2009).

[2] M. S. Li and W. C. Chen, Physics Procedia, vol. 25, (2012).

[3] M. Xu, S. Grant-Muller and Z. Gao, Transport Policy, vol. 41, (2015).

[4] M. R., Omid, N. Deb, R. K. Christopher and M. Kaveh, Transportation Research Part B, vol. 48, (2013).

[5] S. Mishra, S. Khasnabis, S.L. Dhingra, Research in Transportation Economics, vol. 1, no. 38, (2013).

[6] V. Khmel and S. Zhao, "IATSS Research", In Press, (2015).

[7] R. Tiong and K. T. Yeo, International Journal of Project Management, vol. 2, no. 11, (1993).

[8] G. T. Su, "Highway Construction and Financial Leasing", University of International Business and Economics Press, Beijing, (2005).

[9] D. Grimsey and M. K. Lewis, International Journal of Project Management, vol. 2, no. 20, (2002).

[10] J. R. Ezzell and P. P. Vora, The Quarterly Review of Economics and Finance, vol. 1, no. 41, (2001).

[11] H. C. P. Yang and C. T. Liu, Journal of Interdisciplinary Mathematics, vol. 3, no. 12, (2009).

[12] S.Q. Dai, "A Study on Investment and Financing of Highway Project", Central South University, Changsha, (2001).

[13] C. M. Walton and M. A. Euritt, Transportation Research Part A, vol. 4, no. 24, (1990).

[14] T. T. Lin and C. J. Tu, Journal of Interdisciplinary Mathematics, vol. 4, no. 10, (2007).

[15] R. S. Mamon, Journal of Interdisciplinary Mathematics, vol. 3, no. 8, (2005).

[16] Z. Peng, K. A, Journal of Interdisciplinary Mathematics, vol. 3, no. 13, (2010).

[17] H. Lin, W. Y. Lin and Y. C. A. Liu, Journal of Interdisciplinary Mathematics, vol. 1, no. 15, (2012).

\section{Authors}
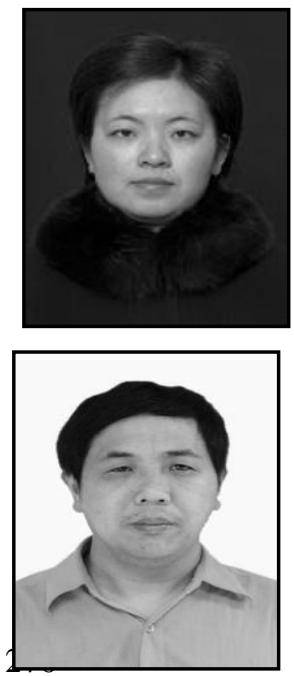

Hong Zhang, is a $\mathrm{PhD}$ candidate at the School of Traffic and Transportation Engineering, Central South University, China. Her major is traffic and transportation planning and management. Her research is mainly focus on highway project management and highway investment and financing problems. Besides, she is also interest in the area of economic, logistic engineering and management.

Dingyou Lei, has over two decades of experience in the field of traffic and transportation planning and management. He specializes in traffic and transportation model and information management. He 
is a great expert in rail transport safety. He is currently working at the School of Traffic and Transportation Engineering, Central South University, as a professor and the head of Traffic and Transportation System Institute.

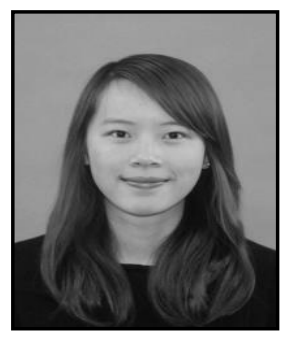

Qiongfang Zeng, is a $\mathrm{PhD}$ candidate at the School of Traffic and Transportation Engineering, Central South University, China. Her research is focus on train platforming problem and urban public transport integration problem. Besides, she is also interested in modern optimization theories such as modern scheduling theory and good at building mathematic modes based on these theories.

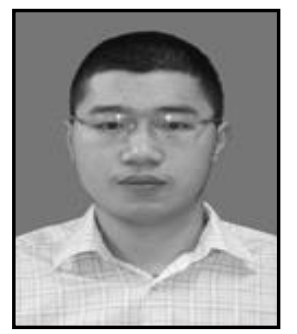

Yinggui Zhang, is a $\mathrm{PhD}$ graduated from Central South University, major in traffic and transportation planning and management. His research interest is in the area of rail and road transportation management, and specializes in transportation scheduling model and algorithm design. He is currently working at the School of Traffic and Transportation Engineering, Central South University as a Lecture and master Supervisor in China. 
International Journal of $u-$ and e- Service, Science and Technology Vol.8, No. 8 (2015) 